\title{
The impact of aeration flow on domestic sewage treatment in a sequenc- ing batch biofilm reactor (SBBR)
}

\author{
S.WANG ${ }^{1}$ \& B.Y.JIANG ${ }^{1}$ \&X.T.LIANG ${ }^{1} \&$ Z.M.SUN ${ }^{2} \&$ H.T.DONG ${ }^{2}$ \\ ${ }^{1}$ School of Municipal and Environmental Engineering, Shenyang Jianzhu University, Shen- \\ yang,China \\ ${ }^{2}$ Guangzhou Municipal Engineering Design \&Research Institute, Guangzhou, China
}

KEYWORD: sequencing batch biofilm reactor (SBBR); aeration amount; simultaneous nitrification and denitrification (SND)

ABSTRACT: A pilot scale sequencing batch biofilm reactor (SBBR) for treating wastewater was used for the purpose of investigating treatment performance under different aeration flows $(10 \mathrm{~m} 3 / \mathrm{h}$ 、 $12 \mathrm{~m} 3 / \mathrm{h} 、 14 \mathrm{~m} 3 / \mathrm{h} 、 16 \mathrm{~m} 3 / \mathrm{h} 、 18 \mathrm{~m} 3 / \mathrm{h} 、 20 \mathrm{~m} 3 / \mathrm{h} 、 22 \mathrm{~m} 3 / \mathrm{h} 、 24 \mathrm{~m} 3 / \mathrm{h})$, by analyzing the changeable concentration of COD、NH4+-N、NH3--N NH2--N and TN both influent and effluent. To find the optimum condition of aeration, provide a reference for practical engineering application. The experimental results showed that, the amount of aeration have less effect on COD removal efficiency but on nitrogen removal. The SBBR could achieve a higher degree of SND, and TN removal could maintain around $62 \%$, the quality of effluent meet level 1B standard of 《Discharge standard of pollutants for municipal wastewater treatment plant $》$ When the aeration flow was controlled the range of $16 \sim 18 \mathrm{mg} / \mathrm{L}$.

\section{INTRODUCTION}

Sequencing batch biofilm reactor (SBBR) as a new process for biological treatment of wastewater, is extensively explored and used home and abroad. The new type of composite biofilm reactor developed from SBR that full of packing (such as fiber packing, activated carbon, ceramic, etc.) It is the intervention of packing that provides more favorable living environment for microbes. Many scholars at home and abroad are committed to relevant research. Foreign scholars have done lots of reach to deal with organic wastewater refractory or polluted seriously. Domestic scholars tend to laboratory model test, to research the sewage treatment of SBBR process, to analyze the effect of removing effect, mechanism, factors and so on, in turn, to explore possible problems when applied in practice.

SBBR technology is to use the microbial metabolism to remove contaminants, so any factors that affect the microbial living environment will lead to different influences on treatment effect, such as temperature, $\mathrm{PH}$, the concentration of $\mathrm{DO}$, aeration time, and selection of packing, $\mathrm{C} / \mathrm{N}$ and so on. This paper attempt to discuss how the sewage treatment performance is affected by aeration amount in a sequencing batch biofilm reactor (SBBR), taking the actual wastewater as object, and using tailor-made SBBR reactor filled with semi soft packing.

\section{Materials and methods}

\section{Reactor configuration}

Experimental reactor was made of galvanized iron plate with size of $3 \mathrm{~m} * 3 \mathrm{~m} * 6 \mathrm{~m}$, which effective volume is $40 \mathrm{~m} 3$. Nine sludge buckets were located at the reactor bottom. Aeration comes from the air compressor to the device, two sets of the same model to replace use. There was a pipe of DN100 connecting to the air compressor export, which inserted at the bottom of the box from the top of the box body. The pipe was divided into two parallel branches and each branch installed six air outlet uniform configurations. Aeration flow was controlled by electronic meter to adjust the mass concentration of DO. The electric control box was used for the reactor operation. We choose the soft solid packing as carrier. Those packing were even covered with two layers in the reactor. The distance between each string of packing was $100 \mathrm{~mm}$. Reaction device is shown in figure 1. 


\section{Wastewater and analytical methods}

Domestic sewage used in this study was obtained from the effluent after fine grille of a water purification plant in Guangzhou. The characteristics of the raw domestic sewage are presented in Table 1.

COD、 $\mathrm{NH}_{4}{ }^{+}-\mathrm{N} 、 \mathrm{NH}_{3}{ }^{-} \mathrm{N} 、 \mathrm{NH}_{2}-\mathrm{N}$ and $\mathrm{TN}$ were determined according to standard methods as shown in references.

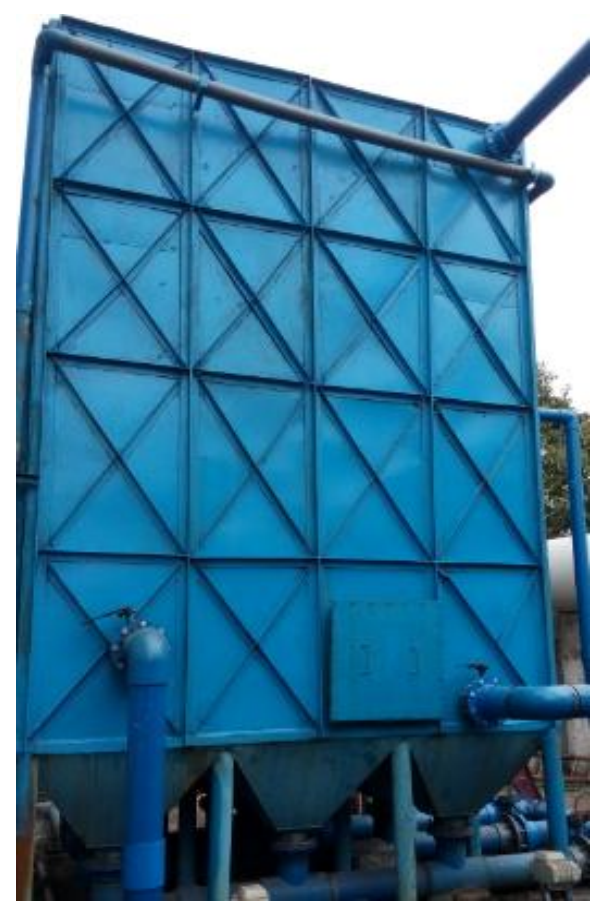

Figure1. Testing apparatus

The reactor was inoculated with activated sludge collected from Guangzhou Municipal Wastewater Treatment Plant. How to judge whether the sludge performance is good as flow: To begin with, we poured $0.5 \mathrm{~L}$ sludge into a breaker, then injected $2 \mathrm{~L}$ actual sewage into the breaker, aerated to the breaker for 5 hours, during aeration we determined COD and $\mathrm{NH}_{4}{ }^{+}-\mathrm{N}$ every hour, if both obvious drop are shown, sludge performance is proved good.

Biofilm configured system was operated under aerobic metabolic functions with a total cycle period of $10 \mathrm{~h}$ consisting of $15 \mathrm{~min}$ of fill phase, $8 \mathrm{~h}$ of reaction (aerobic) phase with recycling, $30 \mathrm{~min}$ of settle phase and 15 min of decant. Aeration amount should not be too large, so as not to shake the biofilm on packing at the early of inoculum phase. The aeration amount was increased $2 \mathrm{~m}^{3} / \mathrm{h}$ from initial $10 \mathrm{~m}^{3} / \mathrm{h}$ at intervals of 3 days. After 16 days' cultivation, biological membrane on packing become thickening gradually, the color become brown, $\mathrm{COD}$ and $\mathrm{NH}_{3}{ }^{-} \mathrm{N}$ removal got above $60 \%$, and all the results indicated the success of biofilm colonization.

After the reactor attained stable conditions, the reactor was operated with aeration flow of 10 $\mathrm{m}^{3} / \mathrm{h}, 12 \mathrm{~m}^{3} / \mathrm{h}, 14 \mathrm{~m}^{3} / \mathrm{h}, 16 \mathrm{~m}^{3} / \mathrm{h}, 18 \mathrm{~m}^{3} / \mathrm{h}, 20 \mathrm{~m}^{3} / \mathrm{h}, 22 \mathrm{~m}^{3} / \mathrm{h}, 24 \mathrm{~m}^{3} / \mathrm{h}$. COD, $\mathrm{NH}_{4}{ }^{+}-\mathrm{N}$, $\mathrm{NH}_{3}^{-}-\mathrm{N}, \mathrm{NH}_{2}^{-}-\mathrm{N}, \mathrm{TN}$ and other indexes were determined at a regular time every day, choosing the average of three trials to analyze.

Table 1. The quality of experimental water.

\begin{tabular}{lc}
\hline Parameter & Value \\
\cline { 2 - 2 } & $\mathrm{mg} / \mathrm{L}$ \\
$\mathrm{COD}_{\text {cr }}$ & $150 \sim 300$ \\
$\mathrm{NH}_{4}{ }^{-}-\mathrm{N}$ & $15 \sim 35$ \\
$\mathrm{PH}$ & $6.5 \sim 7.5$ \\
\hline
\end{tabular}

\section{Results and discussion}




\section{COD removal}

During forming biofilm phase the COD removal rate was on the rise as a whole, even emerged low volatility occasionally. At the moment, since the heterotrophic bacteria in the biofilm were breeding, they urgently needed nutrients to take anaerobic reaction, the organic matter was consumed quickly .It is obvious in Figure. 2 that COD removal maintain above $65 \%$ and concentration of effluent is lower than $50 \mathrm{mg} / \mathrm{L}$ after the reactor ran steadily. It is evident that COD removal was not affected by aeration amount in SBBR.

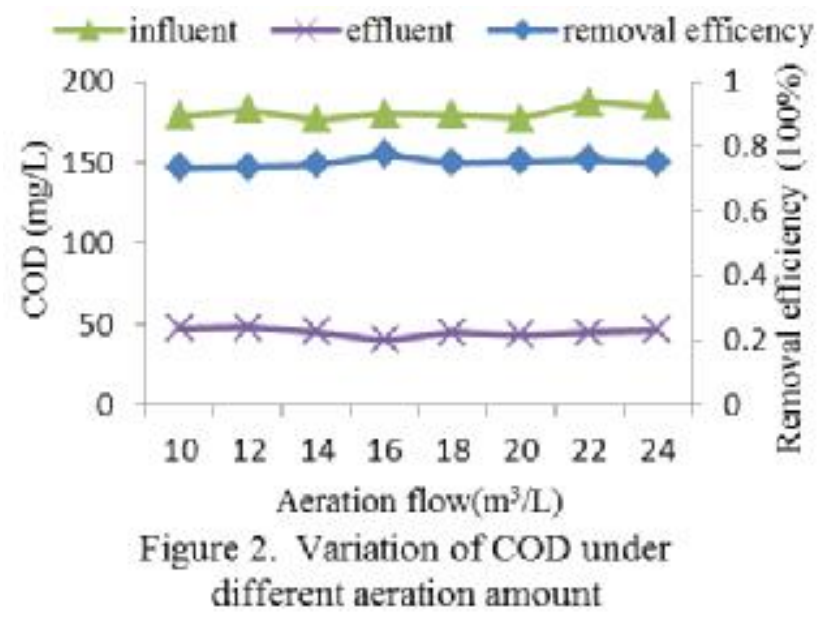

\section{NH4+-N and TN removal}

At $10-12 \mathrm{mg} / \mathrm{L}$ aeration flow, the reactor showed $36 \%$ of COD removal efficiency and maximum $29 \%$ of TN removal efficiency (Figs 3-4). The effluent was still muddy and also smelly even a large number of bubbles floating on the water. It is due to low aeration flow and low DO concentration. The only dissolved oxygen was used to oxidation degradation of organic matter by a number of heterotrophic bacteria. Consequently, the nitrifying bacteria were forced to activity under anoxic and anaerobic state with limited activity. For another,

originally generated $\mathrm{NH}_{3}{ }^{-}-\mathrm{N}$ and $\mathrm{NH}_{2}{ }^{-}-\mathrm{N}$ was reduced to $\mathrm{N}_{2}$ quickly according to that the environment of the moment was conducive to denitrifying bacteria.

At $16-18 \mathrm{mg} / \mathrm{L}$ aeration flow, the reactor showed enhanced performance with respect to $70 \%$ of COD removal efficiency and $65 \%$ of TN removal efficiency removal and after attaining stable conditions the performance remained more or less constant. The ability of nitrifying bacteria was enhanced at the moment, along with increasing of aeration amount, nitrification effect was good. There still being strong denitrification, while denitrification weakening on account of presenting anoxic or anaerobic environment inside the biofilm.

When aeration flow increased gradually, $\mathrm{NH}_{4}{ }^{+}-\mathrm{N}$ removal efficiency increased further, $\mathrm{TN}$ removal efficiency decreases instead. $\mathrm{NH}_{4}{ }^{+} \mathrm{N}$ of effluent increasing was due to the high dissolved oxygen concentration in the reactor. The penetration of dissolved oxygen to biofilm enhanced, and nitrificat ion enhanced, while denitrification greatly abated being the aerobic environment. 


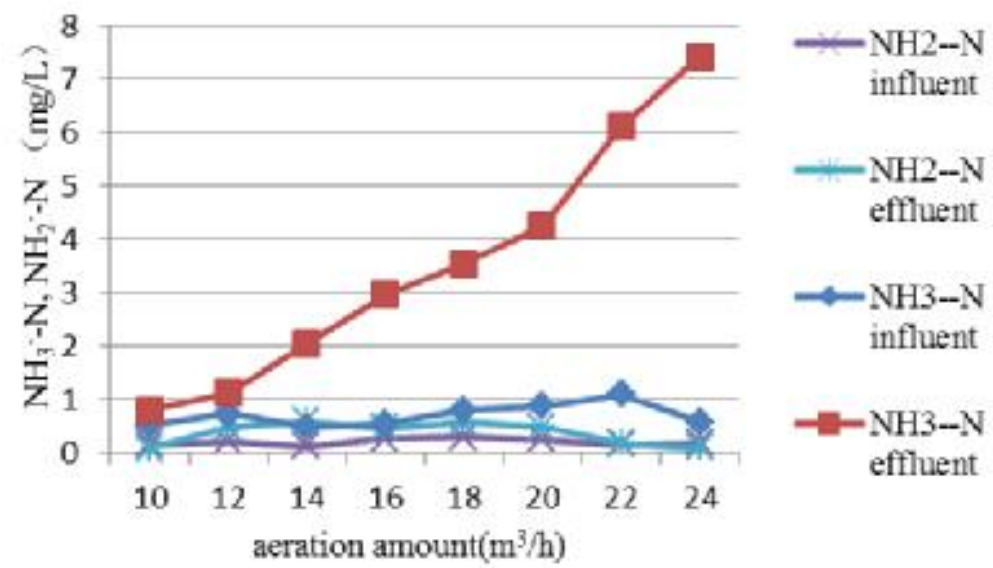

Figure 3. The variation of $\mathrm{NH}_{3}-\mathrm{N}, \mathrm{NH}_{2}-\mathrm{N}$ under different flows

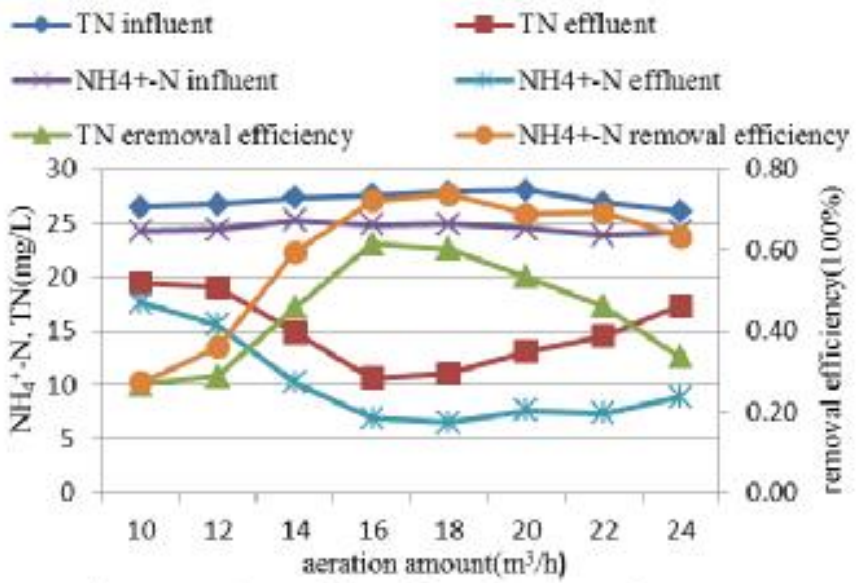

Figure 4. The variation of $\mathrm{NH}_{4}^{+}-\mathrm{N}, \mathrm{TN}$ under different aeration amount

\section{Monocyclic changing of each index}

A representative operation cycle was selected as object to research in greater detail from numerous stable periods. Observe the change of each index influent and effluent of the cycle.

As shown in Figure 5, the environment was beneficial to the growth and reproduction of the conductive nitrification and heterotrophic bacteria but nitrifying bacteria during the first two hours, and the concentration of COD decreased rapidly. It is because the weak oxidation of ammonia that organics were consumed greatly.

During 3 7 hours, the descending of COD developed slowly, while degradation rate of $\mathrm{NH}_{4}{ }^{+}-\mathrm{N}$ began to accelerate, and the concentration of $\mathrm{NH}_{3}{ }^{-} \mathrm{N}$ and $\mathrm{NH}_{2}{ }^{-} \mathrm{N}$ began to rise. Equation (1) was used to calculate the efficiency of the SND process.

$$
\mathrm{SND}(\%)=\left(1-\frac{\mathrm{N}^{-} \text {xproduced }}{\mathrm{NH}^{+} \text {4removal }}\right) \times 100 \%
$$

where $\mathrm{NO}_{\text {-xproduced }}=\left(\mathrm{NH}_{2}{ }^{-} \mathrm{N}+\mathrm{NH}_{3}{ }^{-}-\mathrm{N}_{\text {eff }}-\left(\mathrm{NH}_{2}{ }^{-} \mathrm{N}+\mathrm{NH}_{3}{ }^{-}-\mathrm{N}\right)_{\text {inf }}\right.$; and $\mathrm{NH}_{4 \text { removal }}^{+}=\mathrm{NH}_{4 \text { inf }}{ }^{-}$ $\mathrm{NH}_{4 \text { eff }}^{+}$;

The efficiency of the SND process was around $80 \%$ by computing, and nitrification rate was close to denitrification rate. It is evident that the effect of nitrification and denitrification was better.

Aerating for 7 hours later, TN removal rate in the system reduced, the tendency of $\mathrm{NO}_{\mathrm{x}}{ }^{-}$was no longer obvious. The dissolved oxygen concentration in water would increase if aeration time is extended again, which will reduce the denitrification efficiency, lead to the concentration of $\mathrm{NH}_{3}^{-}-\mathrm{N}$ in water increase, and then influence TN removal efficiency. 


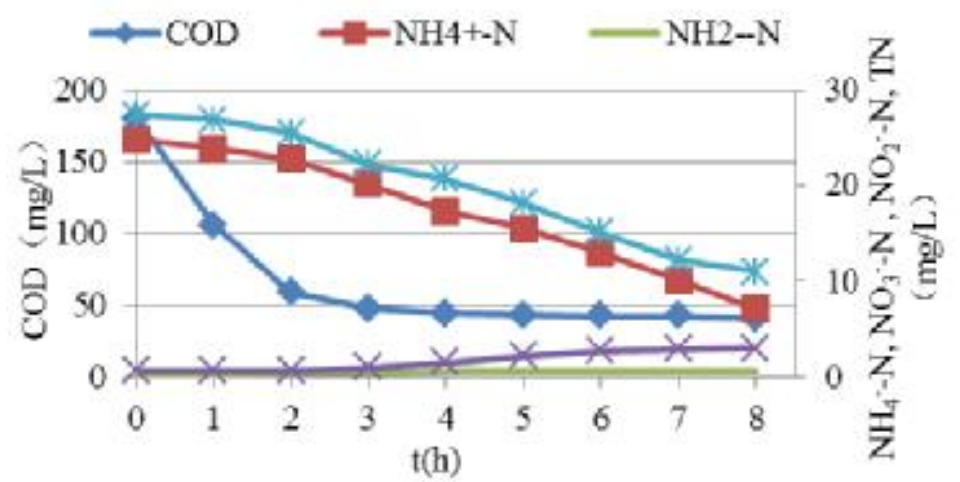

Figure 5. Monocyclic changing of each index

\section{Conclusions}

(1) The amount of aeration has less effect on COD removal efficiency, but on nitrogen removal. The ammonia nitrogen removal efficiency up to $74 \%$, the total nitrogen removal efficiency reached $62 \%$, the quality of effluent meet level 1B standard of 《Discharge standard of pollutants for municipal wastewater treatment plant $\rangle$,When the aeration flow was controlled the range of $16 \sim 18 \mathrm{mg} / \mathrm{L}$.

(2) The SBBR filled with semi soft packing could achieve a higher degree of SND, and performance to treat domestic sewage was good.

(3) The removal of COD started once aeration started, and the removal efficiency declined quickly. While the removal efficiency of NH4+-N began to speed up after 2 hours.

(4) For system with large amount of water, the use of intelligent controlling box is helpful to control aeration time accurately and make the reactor to attain ideal condition.

\section{REFERENCES}

[1] Ding D, Feng C, Jin Y, et al. Domestic sewage treatment in a sequencing batch biofilm reactor (SBBR) with an intelligent controlling system.[J].Desalination, 2011, 276(1):260-265.

[2] Arnz P, Esterl S, Nerger C, et al. Simultaneous loading and draining as a means to enhance efficacy of sequencing biofilm batch reactors. [J]. Water Research, 2000, 34(5):1763-1766.

[3] Mao X M, Zuo H, Qiu H. SBBR technology overview and research progress at home and abroad [J]. Journal of Chongqing University of Education, 2013, 26(6):17-20.

[4] Rong H W, Zhang C, Peng Y Z, et al. Effect of DO on simultaneous nitrification and denitrification in sequencing batch biofilm reactor.[J]. Environmental Science and Technology, 2009,32(8):16-19.DOI:10.3969/j.issn.1003-6504.2009.08.005.

[5] Venkata Mohan S, Chandrasekhara Rao N, Sarma P N. Low-biodegradable composite chemical wastewater treatment by biofilm configured sequencing batch reactor (SBBR).[J]. Journal of Hazardous Materials, 2007, 144(1-2):108-117.

[6] Du P, Sun Z M, Liu Q, et al. The Influence of Stuffing Material in the Biofilm Cultivated Process of SBBR. [J]. Guangdong Chemical Industry. 2010, (12):97-98.

[7] Ding W C, Wu D, Zeng X L, et al. Effect of aeration flow on microbial characteristics and nitrogen transformation of shortcut nitrification processing in a sequencing batch biofilm reactor [J]. Acta Scientiae Circumstantiae, 2012, 32 (9):2112-2118.

[8] Li Y X, Activated sludge process theory and technology. [M]. Beijing:China Architecture and Building Press, 2007.

[9] Jiang S Q, Xiao H W, et al. Study on simultaneous biological nitrogen and phosphorus removal in new sequencing batch biofilm reactor system.Journal of Sichuan University, 2008, 40:64-68. 